\title{
'Epidemiological' treatment in venereal diseases other than syphilis
}

\author{
R. R. WILLCOX \\ St. Mary's Hospital, London, and King Edward VII Hospital, Windsor
}

The use of treatment before diagnosis in non-venereal conditions and in treponemal diseases, including the non-venereal treponematoses (pinta, yaws, and endemic syphilis) and venereal acquired and congenital syphilis, has been described in the previous paper (Willcox, 1973). The term 'prophylactic' or 'preventive' is used when the treatment is given (before or after exposure to risk) to persons who are not definitely known to have been exposed to the disease in question, and the term 'epidemiological' or 'abortive' is used when treatment is applied after exposure to known disease.

The present paper concerns the use of such treatment in certain sexually-transmitted conditions other than venereal syphilis-trichomoniasis, non-gonococcal urethritis, and gonorrhoea. The diseases are considered in ascending order of importance.

\section{Trichomoniasis}

Epidemiological treatment is widely used in the treatment of male consorts of females with vaginal trichomoniasis. Indeed many practising physicians (not, for the record, the author) almost routinely give metronidazole or nitrimidazine tablets to the female to give to her consort without calling him in for examination.

The profile regarding epidemiological treatment is shown in Table I.

Trichomoniasis is a relatively minor condition with a substantial risk of infection to the consorts. There is an extremely effective treatment with very few side-effects and the opportunities for observation if treatment is not used are relatively good for known partners. Even opponents of epidemiological treatment for gonorrhoea and syphilis endorse it for trichomoniasis, e.g. 'The sexual partner should always receive the same treatment after proper investigation, even if it proves impossible to find the organism' (King and Nicol, 1969). Such views must include the considerations that the expedient is desirable, being in the best interests of the patients, and that provided initial investigations are made, either the standards of
TABLE I Trichomoniasis in male consorts: epidemiological profile

\begin{tabular}{|c|c|c|}
\hline Factors & Assessment & Reported figures \\
\hline Risk of infection & $\begin{array}{l}\text { Stated to be } \\
\text { 'virtually certain'a }\end{array}$ & $\begin{array}{l}\text { Slightly less than } \\
50 \text { per cent. }\end{array}$ \\
\hline Seriousness of disease & Trivial & - \\
\hline Difficulty in diagnosis & Cumbersome & $\begin{array}{l}\text { Urethral, prostatic, } \\
\text { and urine smears } \\
\text { and cultures } \\
\text { required }\end{array}$ \\
\hline $\begin{array}{l}\text { Effectiveness of } \\
\text { treatment }\end{array}$ & Very effective & 94-98 per cent. ${ }^{\mathrm{d}}$ \\
\hline Side-effects & Very few & $\begin{array}{l}\text { Less than } 0.2 \text { per } \\
\text { cent. }{ }^{\text {d }}\end{array}$ \\
\hline $\begin{array}{l}\text { Likelihood of spread } \\
\text { if procedure is not } \\
\text { used }\end{array}$ & $\begin{array}{l}\text { Considered very } \\
\text { high }\end{array}$ & $\begin{array}{l}\text { No consolidated } \\
\text { data }\end{array}$ \\
\hline $\begin{array}{l}\text { Facilities for } \\
\text { observation }\end{array}$ & Good & $\begin{array}{l}\text { Best for known } \\
\text { consorts }\end{array}$ \\
\hline
\end{tabular}

${ }^{\mathrm{a}}$ King (1968)

bWeston and Nicol (1963)

cWillcox (1960)

dKeighley (1971)

physicians are not lowered or if they are the procedure is justified. The consequences of the disease and its treatment may be trivial, including possible medico-legal difficulties, the gonococcus perhaps being considered able to provide greater proof of marital infidelity than the flagellated protozoon for which some non-venereal means of contagion can always be suggested.

Nevertheless it is observed that the demonstrable risk of infection when tests are carefully done may be only 50 per cent. or less (Table II) although, of course, the actual infection rate may be higher.

There are no reports of the pre-exposure chemoprophylaxis of trichomoniasis, presumably because the disease is not serious enough to warrant it, although such prophylaxis should be effective with single oral doses of metronidazole (Woodcock, 1972). 
TABLE I I Trichomoniasis: incidence in male contacts

\begin{tabular}{|c|c|c|c|}
\hline $\begin{array}{l}\text { Time since exposure } \\
\text { (days) }\end{array}$ & $\begin{array}{l}\text { No. of } \\
\text { contacts }\end{array}$ & T. vag. + & $\begin{array}{l}\text { Per cent. } \\
\text { positive }\end{array}$ \\
\hline $\begin{array}{r}2-14 \\
14-60\end{array}$ & $\begin{array}{r}154 \\
52\end{array}$ & $\begin{array}{l}66 \\
27\end{array}$ & $\begin{array}{l}42 \cdot 9 \\
51 \cdot 9\end{array}$ \\
\hline $2-60$ & 206 & 93 & $45 \cdot 1$ \\
\hline
\end{tabular}

(Urethral, urine, and prostatic smears and cultures: data from Weston and Nicol, 1963)

\section{Non-gonococcal urethritis}

The epidemiological profile concerning the epidemiological treatment of female contacts of males with non-gonococcal urethritis is shown in Table III. It is based on the assumption that those who use the procedure believe that Chlamydia may be responsible for the bulk of cases.

TABLE II F Female consorts of males with non-gonococcal urethritis: epidemiological profile

\begin{tabular}{|c|c|c|}
\hline Factors & Assessment & Reported figures \\
\hline Risk of infection & $\begin{array}{l}\text { Unknown: probably } \\
\text { high }\end{array}$ & None \\
\hline Seriousness & Can be serious & None for females \\
\hline $\begin{array}{l}\text { Difficulties in } \\
\text { diagnosis }\end{array}$ & $\begin{array}{l}\text { Research basis } \\
\text { only }\end{array}$ & $\begin{array}{l}\text { Chlamydia has been } \\
\text { demonstrated in } 30 \text { to } \\
44 \text { per cent. of } \\
\text { males }^{3} \text { b }\end{array}$ \\
\hline $\begin{array}{l}\text { Effectiveness of } \\
\text { treatment }\end{array}$ & Inconclusive & $\begin{array}{l}\text { Ineffectivec d } \\
\text { Post-gonococcal } \\
\text { non-gonococcal } \\
\text { urethritis reduced } \\
\text { from } \frac{2}{3} \text { to } \frac{1}{4} e^{\text {e }}\end{array}$ \\
\hline Side-effects & $\begin{array}{l}\text { Some with prolonged } \\
\text { treatment }\end{array}$ & $\begin{array}{l}\text { Those of tetracyclines } \\
\text { or drugs used }\end{array}$ \\
\hline $\begin{array}{l}\text { Likelihood of spread } \\
\text { if procedure is not } \\
\text { used }\end{array}$ & Not known & None \\
\hline
\end{tabular}

"Dunlop, Hare, Darougar, Jones, and Rice (1969); bDunlop (1972); "Willcox (1953), "Rosedale (1959), "Holmes, Jonhson, Floyd, and Kvale (1967); 'Siboulet, Bonattour, Egger, and Majewski (1970)

However, Chlamydia has so far been demonstrated in less than half of male patients. Moreover the risk of infection, the natural course of the disease, and the likelihood of subsequent spread are unknown, as is the duration of treatment required positively to eradicate the organism. With no reliable tests for Chlamydia within the scope of the average venereal diseases clinic or laboratory, the usefulness of followup examinations for women is also small.

Non-gonococcal urethritis can be serious. In males Reiter's syndrome may occur in around 1 per cent. or less of cases (Department of Health and Social
Security, 1971) and urethral stricture has been reported (Hancock, 1959; Csonka, 1965). In females salpingitis has also been noted (Dunlop, 1972) but the precise relationship of complications with demonstrable Chlamydia still remains to be defined.

There is no published evidence to suggest that the epidemiological treatment of female contacts is effective in preventing recurrences in infected males: indeed the only paper on the subject (Rosedale, 1959) failed to show this. Even the evidence that the use of tetracycline instead of penicillin in the treatment of gonorrhoea reduces the incidence of post-gonococcal urethritis-which has not yet been with certainty defined as due to Chlamydia in any large series-is conflicting. Willcox (1953) reported no such effect, and Holmes, Johnson, Floyd, and Kvale (1967) stated that the incidence of this complication in the Far East could be reduced from about two-thirds to one-quarter if tetracyclines were used instead of penicillin. Lower rates of post-gonococcal urethritis when penicillin was not used were also reported in France by Siboulet, Bouattour, Egger, and Majewski (1970).

In the absence of firm data on which to base the procedure, the writer does not use it routinely but only for women with definite clinically evident cervicitis and for those whose male consort repeatedly relapses. Nevertheless others, even opponents of epidemiological treatment in gonorrhoea and syphilis for which basic data are much more easily obtained, do in fact recommend it. For example: 'It has been the usual practice to give women with non-specific urogenital infection treatment similar to that used for men. Even if a female patient is free from symptoms and signs, it may be wise to treat her in the hope of preventing re-infection of her consort' (King and Nicol, 1969).

\section{Gonorrhoea}

EPIDEMIOLOGICAL PROFILE

Epidemiological treatment of gonorrhoea is widely used by venereologists, at least on a selective basis in females and passive homosexuals, when the initial examination of the smears has proved negative and in advance of the results of the cultures. It is no part of the author's thesis that treatment should be given for any venereal diseases without initial examination and one series of tests; it is only stressed that the limitations of the available diagnostic procedures and the delays arising therefrom or due to attempting repeated tests, may nullify or reduce the value of the treatment ultimately given.

The epidemiological profile for female contacts of male patients with gonorrhoea is shown in Table IV (overleaf). 
TABLE IV Female consorts of males with gonorrhoea: epidemiological profile

\begin{tabular}{|c|c|c|}
\hline Factors & Assessment & Reported figures \\
\hline Risk of infection & Very high & 75.0 to 88.6 per cent. ${ }^{a}$ \\
\hline $\begin{array}{l}\text { Seriousness of } \\
\text { disease }\end{array}$ & Can be serious & $\begin{array}{l}\text { Negligible if } \\
\text { properly treated }\end{array}$ \\
\hline $\begin{array}{l}\text { Difficulties in } \\
\text { diagnosis }\end{array}$ & $\begin{array}{l}\text { Prolonged, } \\
\text { sometimes difficult }\end{array}$ & $\begin{array}{l}\text { Up to eight } \\
\text { examinations may be } \\
\text { required }^{\mathrm{b}}\end{array}$ \\
\hline $\begin{array}{l}\text { Effectiveness of } \\
\text { treatment }\end{array}$ & Effective & $\begin{array}{l}\text { May be } 96 \text { to } 98.5 \text { per } \\
\text { cent. c d e }\end{array}$ \\
\hline Side-effects & Very few & 0.5 to 0.6 per cent. ${ }^{f} \mathrm{~g}$ \\
\hline $\begin{array}{l}\text { Likelihood of } \\
\text { spread if } \\
\text { procedure not used }\end{array}$ & $\begin{array}{l}\text { High with infrequent } \\
\text { clinic sessions } \\
\text { Poor attenders } \\
\text { Those about to } \\
\text { travel } \\
\text { Itinerants } \\
\text { Promiscuous persons } \\
\text { Regular consorts }\end{array}$ & $\begin{array}{l}\text { See subsequent } \\
\text { Tables }\end{array}$ \\
\hline
\end{tabular}

aNicol (1948), b'Keighley (1957); cHooton and Nicol (1967) aSchofield, Masterton, Moffett, and McGill (1969); eBrø-Jorgensen and Jensen (1971); 'Rudolph (1971); 8 Wilkinson (1972)

\section{RISK OF INFECTION}

All would agree that, if the risk of infection in the contacts of a given disease were 100 per cent., the necessity for the performance of cumbersome diagnostic procedures would cease to exist. In gonorrhoea the reported risk of disease in female consorts is very high (Table V) and the majority of infected females will have no symptoms and will only attend when nominated as contacts.

TABLE V Gonorrhoea found in named female contacts by repeated examinations

\begin{tabular}{|c|c|c|c|c|c|}
\hline \multirow{2}{*}{ Authors } & \multirow{2}{*}{ Date } & \multirow{2}{*}{ Method } & \multirow{2}{*}{$\begin{array}{l}\text { No. of } \\
\text { cases }\end{array}$} & \multicolumn{2}{|c|}{ Positive } \\
\hline & & & & No. & Per cent. \\
\hline Nicol & 1948 & $\begin{array}{l}\text { Smear and culture } \\
\text { Smear and culture } \\
\text { plus suggestive } \\
\text { evidence }^{\mathrm{a}}\end{array}$ & 132 & $\begin{array}{r}99 \\
117\end{array}$ & $\begin{array}{l}75 \cdot 0 \\
88 \cdot 6\end{array}$ \\
\hline $\begin{array}{l}\text { Thin, } \\
\text { Williams, } \\
\text { and Nicol }\end{array}$ & 1971 & $\begin{array}{l}\text { Smear, culture } \\
\text { and immuno- } \\
\text { fluorescence }\end{array}$ & 157 & 144 & $91 \cdot 7$ \\
\hline
\end{tabular}

aFifteen had a positive gonococcal complement-fixation test

In the two series described, gonorrhoea was diagnosed in from 75.0 to 91.7 per cent. of cases.

In males, on the other hand, the risk of contracting gonorrhoea from an infected female has been assessed as only 22 per cent. (Holmes, Johnson, and Trostle, 1970 ) and the great majority develop symptoms when infected. Epidemiological treatment is there- fore much less used in males with suspected incubating urethral infections.

\section{SERIOUSNESS OF DISEASE}

That gonorrhoea can be serious is not in dispute. In the female the complication to be feared is salpingitis with the possibility of sterility or ectopic pregnancy. Salpingitis may arise in about 10 per cent. of female cases (Gisslén, Hellgren, and Starck, 1961; Rees and Annels, 1969), of which approximately one-third may become sterile (Gisslén and others, 1961). Complications are extremely rare in the treated patient.

\section{DIFFICULTIES IN DIAGNOSIS}

There are greater difficulties in the diagnosis of gonorrhoea of the female genitalia and of anal infections in both sexes than of penile infections. Indeed, in the female, using smears and cultures of the urethra and cervix, up to eight examinations may be required (Keighley, 1967). In the series reported by Catterall (1970), over one-third of patients were not diagnosed by smear or culture at the initial visit and over one in ten not until the third or fourth examination.

Of relevance to the consideration of epidemiological treatment is the proportion of cases in which the diagnosis can be made immediately in the clinic at the first visit, thus enabling the patient to be treated at once, some days in advance of the results of culture.

Some reported experience of the detection of gonorrhoea in females by means of a Gram-stained smear at the first visit is shown in Table VI.

TABLE VI Diagnosis of gonorrhoea in females by Gram-stained smear at the first attendance

\begin{tabular}{|c|c|c|c|c|}
\hline \multirow{2}{*}{ Author } & \multirow{2}{*}{ Date } & \multirow{2}{*}{$\begin{array}{l}\text { No. of } \\
\text { infected } \\
\text { women }\end{array}$} & \multicolumn{2}{|c|}{ Positive smears } \\
\hline & & & No. & Per cent. \\
\hline $\begin{array}{l}\text { Schmidt } \\
\text { Catterall } \\
\text { Thin and others }\end{array}$ & $\begin{array}{l}1961 \\
1970 \\
1971\end{array}$ & $\begin{array}{r}108 \\
95 \\
144\end{array}$ & $\begin{array}{l}24 \\
48 \\
84\end{array}$ & $\begin{array}{l}22 \cdot 2 \\
50 \cdot 5 \\
58 \cdot 3\end{array}$ \\
\hline Total & & 347 & 156 & $45 \cdot 0$ \\
\hline
\end{tabular}

Only about one-half of cases may thus be diagnosed by this method. If direct immunofluorescence is used, higher yields can be obtained (e.g. $75 \cdot 8$ per cent. by Thin and others, 1971).

All venereologists treating their cases on smear evidence do so knowing the limitations of the method in the female; some will not be confirmed by culture and indeed some of the organisms seen may not prove to be gonococci at all. Among 229 cases reported by Nicol (1948), the positive smear findings which dictated treatment were never confirmed by culture 
in 43.7 per cent., and in the same series approximately 25 per cent. were treated because of positive cultures when the smears had been negative. Such discrepancies are not unusual and the efficiency of cultures may fluctuate from time to time.

Treating on smear evidence in advance of the result of culture is general practice in Great Britain; according to a British Cooperative Clinical Group Study (1971), this procedure was followed in 92 per cent. of female and 98 per cent. of male clinics (Willcox, 1972). In some cases treatment was withheld for medico-legal or other reasons, and in very few clinics no immediate reporting of smears was available and the smear results were received at the same time as those of the cultures.

It is generally agreed that the specificity of the Gram-stain and also to some extent immunofluorescence (which was being conducted on a limited scale, usually on a research basis, in only sixteen of 206 clinics participating in the British Cooperative Clinical Group Study) is also in doubt. For example, neither method will distinguish for certain the gonococcus from the meningococcus, and yet it has been recently shown that the latter organism may occasionally be found in the rectum and also in the endocervix (Keys, Hecht, and Chow, 1971).

Moreover, in a number of countries (e.g. the U.S.A.), a positive oxidase test on cultured organisms is considered sufficient evidence for a presumptive diagnosis of the gonococcus and therefore in many cases, even if cultures do prove positive, the organism is not precisely identified for medico-legal purposes. In addition, the high incidence of rectal infections with gonorrhoea has been known for many years (Nicol, 1948), and yet rectal smears and cultures are by no means routinely performed, for a variety of reasons.

The accurate diagnosis of gonorrhoea is thus highly complex and time-consuming. To do it properly requires repeated Gram-stained and immunofluorescent smears and cultures from the urethra, cervix, Bartholin's ducts, rectum, tonsils, and sub-lingual areas, and it is probable that no clinic in the world even attempts this on a routine basis. Those who use epidemiological treatment do so in recognition of this fact, and effect an inevitable compromise with the available diagnostic methods in order to have time on their side with a view to better prevention.

\section{EFFECTIVENESS OF TREATMENT}

Treatment results in gonorrhoea, especially for the female, can vary widely (Schofield and others, 1969). Also rectal infections are less responsive than urethral or cervical infection to treatment with benzyl penicillin (Fluker and Hewitt, 1970; Eriksson, 1971).
The effectiveness of epidemiological treatment of gonorrhoea depends on that of the routine treatment used. The latter can be 96 to 98.5 per cent. successful (see Table IV). At the same time, if effective treatment is used at once, the possibility of complications is eliminated.

\section{INCIDENCE OF SIDE-EFFECTS}

Provided patients are questioned concerning a history of previous penicillin allergy, and are given an alternative drug when a positive history is obtained, the side-effects of penicillin in venereal disease clinics are very few (see Table IV). Indeed, amongst patients given epidemiological treatment for gonorrhoea in the U.S.A., the incidence was 0.46 per cent. (Rudolph, 1971).

LIKELIHOOD OF SPREAD IF THE PROCEDURE IS NOT USED Spread of gonorrhoea in the community by untreated contacts is obviously likely in the cases of patients who are about to travel, itinerants, known bad attenders, regular consorts, and promiscuous persons, and in late pregnancy the eyes of the baby are at risk. The need for prompt treatment increases inversely with the availability of facilities. In the United Kingdom no less than 34 per cent. of 206 venereal disease clinics in the British Cooperative Clinical Group Study (1971) operated for 3 hours a week or less and 57 per cent. for 6 hours or less. Thus, in one-third of clinics at least 3 weeks might elapse before the results of three groups of tests were obtained, and in this time the infection is likely to be spread or complications may develop.

Moreover, among patients with gonorrhoea, default rates are high. A sizeable number of patients even fail to return after the first visit to obtain the result of the initial culture or blood test. At St. Mary's Hospital, London, $15 \cdot 8$ per cent. of male patients are immediate defaulters (Table VII).

TABLE VII Male patients at St. Mary's Hospital, London, not returning after the first visit

\begin{tabular}{|c|c|c|c|c|}
\hline \multirow{2}{*}{ Disease } & \multirow{2}{*}{$\begin{array}{l}\text { No. } \\
\text { treated }\end{array}$} & \multirow{2}{*}{$\begin{array}{l}\text { No. } \\
\text { followed }\end{array}$} & \multicolumn{2}{|c|}{ Those failing to return } \\
\hline & & & No. & Per cent. \\
\hline $\begin{array}{l}\text { Gonorrhoea } \\
\text { NGU }\end{array}$ & $\begin{array}{l}3,508 \\
2,184\end{array}$ & $\begin{array}{l}2,953 \\
1,876\end{array}$ & $\begin{array}{l}555 \\
308\end{array}$ & $\begin{array}{l}15 \cdot 8 \\
14 \cdot 1\end{array}$ \\
\hline Total & 5,692 & 4,829 & 863 & $15 \cdot 2$ \\
\hline
\end{tabular}

Much higher immediate defaulter rates have been reported in some other clinics, even in series involving treatment evaluations which are likely to have been better followed than the ordinary routine cases. In fourteen such reported series ( 7 in the U.S.A.; five in 
the U.K.; one in Norway; one in Australia), the immediate default rate was 30.7 per cent. in males (Table VIII) and 33.5 per cent. in females (Table IX).

TABLE VIII Male patients with gonorrhoea failing to return after the first visit in various countries

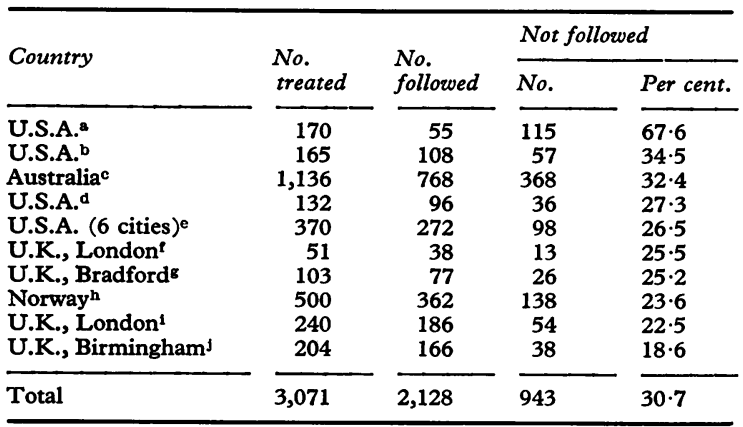

aDuncan, Glicksman, Knox, and Holder (1971); bCornelius and Domescik (1970); 'Smithurst (1970); dMcLone, Billings, Hardegree, and Hackney (1968a); 'Cornelius (1970); 'Farrell (1969); BOller (1967); hGjessing and Odegaard (1967); ${ }^{\text {I} C s o n k a ~(1969) ; ~ J o u h a r ~ a n d ~}$ Fowler (1968)

TABLE IX Female patients with gonorrhoea failing to return after the first visit

\begin{tabular}{|c|c|c|c|c|}
\hline \multirow{2}{*}{ Country } & \multirow{2}{*}{$\begin{array}{l}\text { No. } \\
\text { treated }\end{array}$} & \multirow{2}{*}{$\begin{array}{l}\text { No. } \\
\text { followed }\end{array}$} & \multicolumn{2}{|c|}{ Not followed } \\
\hline & & & No. & Per cent. \\
\hline $\begin{array}{l}\text { U.S.A.a } \\
\text { U.S.A.b } \\
\text { U.S.A.c } \\
\text { U.K., Bradford }{ }^{\mathrm{d}}\end{array}$ & $\begin{array}{r}100 \\
85 \\
148 \\
37\end{array}$ & $\begin{array}{r}62 \\
56 \\
100 \\
28\end{array}$ & $\begin{array}{r}38 \\
29 \\
48 \\
9\end{array}$ & $\begin{array}{l}38 \cdot 0 \\
34 \cdot 1 \\
32 \cdot 4 \\
24 \cdot 3\end{array}$ \\
\hline Total & 370 & 246 & 124 & 33.5 \\
\hline
\end{tabular}

${ }^{a}$ McLone and others (1968a); ${ }^{b}$ McLone, Scotti, Mackey, and Hackney (1968b); 'Cornelius and Domescik (1970); dOller (1967)

EXTENT OF PRACTICE OF PROPHYLACTIC AND EPIDEMIOLOGICAL TREATMENT IN GONORRHOEA IN THE UNITED KINGDOM

Considering all the factors involved, there is little wonder that the practice of giving epidemiological treatment to contacts of patients with gonorrhoea in advance of the cultural findings is widespread. Some engage in the procedure as a routine, believing it obligatory that the female contact should always be treated (Siboulet and others, 1970); others undertake it only on a selective basis, but virtually all venereologists would wish patients to be examined and tests taken at the first attendance, treatment not to be given to unexamined persons, and treated persons to be followed in the same manner as when the disease is known to be present.

The practice in the United Kingdom regarding the use of either prophylactic or epidemiological treatment routinely in all cases, according to the findings of the British Cooperative Clinical Group survey (1971) are shown in Table X.

TABLE X Percentage of clinics in the U.K. giving either epidemiological or prophylactic treatment for gonorrhoea in most cases

\begin{tabular}{|c|c|c|}
\hline Indication & Males & Females \\
\hline Prophylactic & 1.0 & 0.5 \\
\hline Epidemiological & $5 \cdot 8$ & $22 \cdot 0$ \\
\hline $\begin{array}{l}\text { Epidemiological plus } \\
\text { clinical evidence }\end{array}$ & $12 \cdot 2$ & $28 \cdot 4$ \\
\hline
\end{tabular}

British Cooperative Clinical Group (1971); Willcox (1972)

\section{Prophylactic treatment}

The use of post-exposure prophylactic treatment when the venereal status of the source of exposure is unknown was not approved. Nevertheless, the procedure was employed in selected cases in 15 per cent. of clinics, its use being advocated in some cases when others are at risk (e.g. wives of husbands returning home from overseas after contact of a dubious nature while in transit-Willcox, 1954). It has also been used, as has pre-exposure prophylaxis, among naval personnel entering port after a long spell at sea when intercourse between the men and a highly infected shore population is very likely indeed, and a considerable reduction of gonorrhoea was noted compared with untreated controls (Eagle, Gude, Beckmann, Mast, Sapero, and Schindeldecker, 1949; Babione, Hedgecock and Ray, 1952). However, naval personnel are closed populations and can subsequently be observed on board ship without danger to the community. There are therefore few advantages to offset the disadvantages in relation to antibiotic hypersensitivity and the danger of fostering of microbial resistance as well as the possible masking of the disease, especially if oral tablets are used, as the doses given are not likely to be curative for gonorrhoea today in many of the areas in which such an approach might be considered.

\section{Epidemiological treatment}

This was used routinely in only 5.8 per cent. of male clinics but in 22 per cent. of female clinics. It received wider acceptance if clinical evidence of gonorrhoea was forthcoming than if it were not, being given in 28.4 per cent. of female clinics.

When those undertaking epidemiological treatment for selected patients were included, it was apparent that the procedure was used for females when considered desirable in more than two-thirds of clinics, and in more than three-quarters if clinical suspicion were added (Table XI, opposite). 
TABLE XI Percentage of clinics in the U.K. giving either epidemiological or prophylactic treatment for gonorrhoea at least in selected cases

\begin{tabular}{|c|c|c|}
\hline Indication & Males & Females \\
\hline Prophylactic & $13 \cdot 6$ & $15 \cdot 2$ \\
\hline Epidemiological & $18 \cdot 6$ & $68 \cdot 7$ \\
\hline $\begin{array}{l}\text { Epidemiological plus } \\
\text { clinical evidence }\end{array}$ & $22 \cdot 2$ & $76 \cdot 1$ \\
\hline
\end{tabular}

British Cooperative Clinical Group (1971)

Selection was most likely to be used for:

\section{Wives}

Regular consorts

Pregnant women

Those about to travel

Known or suspected defaulters

Known or suspected promiscuous persons

Additional clinical reasons

Passive male homosexuals

\section{British Cooperative Clinical Group (1971)}

Many of the opponents in principle of epidemiological treatment will nevertheless be tempted to give such treatment, and even post-exposure prophylactic treatment also, to individuals listed below, and some may even succumb to the temptation:

Themselves

Their mistresses

Their friends

Their accountant

Their bank manager

Private patients

Bishops and clergy

High trade union officials

Senior health administrators

Their medical colleagues

(and relatives)

Their wives and family

$\star$ Bijkerk (1971)

\section{Summary and conclusions}

(1) The use of prophylactic (preventive) and epidemiological (abortive) treatment in non-venereal conditions and in treponemal disease including venereal syphilis have been described in an earlier paper. In the present communication current practices in relation to trichomoniasis, non-gonococcal urethritis, and gonorrhoea are reviewed in relation to their epidemiological profiles.

(2) The practice of epidemiological treatment is widespread in relation to the male contacts of females with vaginal trichomoniasis. It is also used to treat the female consorts of males with non-gonococcal urethritis, although the data on which the procedure is based are yet far from firm.

(3) In gonorrhoea there is little support for the use of prophylactic treatment, except by some in special cases, but there is considerable acceptance of the epidemiological treatment of the female contacts of males with gonorrhoea in advance of the culture results when smears have failed to show the disease. Epidemiological treatment is used routinely in up to 28 per cent. of British clinics and on a selective basis in three-quarters of them. British venereologists, however, would require that all patients be examined by smear and culture at the first visit and that treated patients be followed as if the disease had in fact been found.

(4) The use of epidemiological treatment still engenders much controversy, for fear that it may be adopted indiscriminately without examination and follow-up of the patients, and that lower standards of management may ensue. Much misunderstanding has arisen from a lack of comprehension of what is or is not being advocated. Its users are not, for example, recommending that a patient should be treated without examination. In a paper on the subject written 18 years ago (Willcox, 1954), the final conclusion was: 'Indiscriminate treatment with penicillin before diagnosis is not advocated in this paper. We must not squander our antibiotic heritage. This new and valuable tool must be handled properly and it requires no lowering of our standards of care and foresight, but rather the reverse.' This remains the final conclusion to-day.

\section{References}

BABIONE, R. W., HEDGECOCK, L. E., and RAY, T. F. (1952) U.S. armed Forces med. $\mathcal{F} ., 3,973$

BIJKERK, H. (1971) Personal communication

British Cooperative Clinical Group (1971) Brit. f. vener. Dis., 47, 17

BRø-JoRgensen, A., and Jensen, T. (1971) Ibid., 47, 443

Catterall, R. D. (1970 Ibid., 46, 122

CORNelIUS, C. E. (1970) Ibid., 46, 330

- and Domescik, C. (1970) Ibid., 46, 212

CsONRA, G. W. (1965) Ibid., 41, 1

- (1969) Postgrad. med. F., 45, Suppl. (November), p. 77

Department of Health and Social Security (1971) 'Report of the Chief Medical Officer for the Year 1970', 61-70. H.M. Stationery Office, London

Duncan, W. C., Glicksman, J. M., Knox, J. M., and HoLDER, W. R. (1971) Brit. F. vener. Dis., 47, 364

DunLop, E. M. C. (1972) Address given to Nursing Staff, St. Mary's Hospital, London

-, HARE, M. J., Darougar, S., Jones, B. R., and RICE, N. S. C. (1969) f. infect. Dis., 120, 463 
Eagle, H., Gude, A. V., Beckmann, G. E., Mast, G., SAPERO, J. J., and SCHINDELDECKER, J. B. (1949) $\mathcal{f}$. Amer. med. Ass., 140, 940

ErIKsson, G. (1971) Acta derm.-venereol. (Stockh.), 51, 305

FARRELL, L. (1969) Brit. F. vener. Dis., 45, 232

FlukeR, J. L., and HewitT, A. B. (1970) Ibid., 46, 454

Gisslén, H., Hellgren, L., and Starck, V. (1961) Bull. Wld Hlth Org., 24, 367

GJEssing, H. C., and ÖDEgaARD, K. (1967) Brit. F. vener. Dis., 43, 133

HANCOCK, J. A. H. (1959) Urol. int. (Basel), 9, 258

Holmes, K. K., Johnson, D. W., Floyd, T. M., and Kvale, P. A. (1967) F. Amer. med. Ass., 202, 467

$\longrightarrow,-$, and Trostle, H. J. (1970) Amer. F. Epidemiol., 91, 170

Hooton, W. F., and Nicol, C. S. (1967) Postgrad med.f., 43, Suppl. May, p. 68

JouHAR, A., and FowLER, W. (1968) Brit. F. vener. Dis., 44, 223

KEIGHLEY, E. (1957) Ibid., 33, 105

(1971) Brit. med. F., 1, 207

KeYs, T. F., HeChT, R. H., and ChOW, A. W. (1971) New Engl. F. Med., 285, 505

King, A. J. (1968) Brit. med. F., 4, 581

- and Nicol, C. S. (1969) 'Venereal Diseases', 2nd ed. Baillière, Tindall and Cassell, London

MCLONE, D. C., Billings, T. E., HARDEGREe, W. E., and HACKNEY, J. F. (1968a) Brit. F. vener. Dis., 44, 218

- SCOTTI, A. T., MACKEY, D. M., and HACKNEY, J. F. (1968b) Ibid., 44, 220

Nicol, C. S. (1948) Ibid., 24, 26

Oller, L. Z. (1967) Postgrad. med. F., 43, Suppl. (August), p. 124

ReEs, E., and ANNELS, E. H. (1969) Brit. F. vener. Dis., 45, 205

Rosedale, H. (1959) Ibid., 35, 245

RUDOLPH, A. H. (1971) Paper presented at National VD Conference, Atlanta, Georgia

SCHмidT, H. (1961) Ugeskr. Laeg., 123, 744

SChofield, C. B. S., MASTERTon, G., Moffett, M., and MCGILL, M. I. (1969) Postgrad. med. F., 45, Suppl. (November), p. 81

Siboulet, A., Bouattour, H., Egger, E., and Majewski, E. (1970) Bull. Soc. franc. Derm. Syph., 77, 870

Smithurst, B. A. (1970) Brit. F. vener. Dis., 46, 398

Thin, R. N. T., WILliams, I. A., and Nicol, C. S. (1971) Ibid., 47, 27

Weston, T. B. T., and Nicol, C. S., (1963) Ibid., 39, 251

Wilkinson, A. E. (1972) \}. roy. Coll. Phycsns (Lond.), 6, 175

Willcox, R. R. (1953) Amer. F. Syph., 37, 383

- (1954) Brit. F. vener. Dis., 30, 7

- (1960) Ibid. 36, 175

- (1972) Postgrad. med. F., 48, Suppl. (January,) p. 71

- (1973) Brit. F. vener. Dis., 49, 107

WooDCock, K. R. (1972) Ibid., 48, 65
Traitement épidémiologique dans les maladies vénériennes autres que la syphilis

\section{SOMMAIRE ET CONCLUSIONS}

(1) L'emploi du traitement prophylactique (préventif) et épidémiologique (abortif) dans les maladies non vénériennes et dans les tréponématoses, dont la syphilis vénérienne, ont été décrits dans un article antérieur. Dans la présente communication, on passe en revue les pratiques habituelles touchant la trichomonase, les urétrites non gonococciques et la gonococcie, ceci en relation avec leurs caractéristiques épidémiologiques.

(2) L'emploi d'un traitement épidémiologique est largement répandu pour les partenaires masculins de femmes atteintes de vaginite à trichomonas. Il est aussi employé pour traiter les partenaires d'hommes atteints d'urétrite non gonococcique, quoique les éléments sur lesquels reposent une telle pratique soient loin d'être fermement établis.

(3) Dans la gonococcie, il y a peu de chose pour légitimer l'emploi du traitement prophylactique, sauf pour quelques cas spéciaux, mais le traitement épidémiologique est largement accepté pour les femmes ayant été en contact avec des hommes atteints de gonococcie, ceci avant le résultat de la culture lorsque les lames n'ont pas réussi à mettre la maladie en évidence. Le nombre des cliniques britanniques qui emploient le traitement épidémiologique en routine atteint 28 pour cent et les trois-quarts l'emploient sur des bases sélectives. Les vénéréologues britanniques cependant demandent que tous les sujets soient examinés par lame et culture à la première visite et que ceux qui reçoivent le traitement soient suivis comme si l'on avait effectivement constaté la maladie.

(4) L'emploi du traitement épidémiologique suscite toujours beaucoup de polémique, dans la crainte qu'il soit employé d'une manière indiscriminée, sans examen ni surveillance des sujets, et qu'il en résulte un affaiblissement de la qualité des soins. Beaucoup de malentendus sont nés du manque de compréhension de ce qui est ou n'est pas préconisé. Ceux qui l'utilisent ne recommandent pas, par exemple, qu'un sujet soit traité sans examen. La conclusion d'un article écrit il y a dix-huit ans (Willcox, 1954), était: 'Un traitement indiscriminé avec la pénicilline avant le diagnostic n'est pas préconisé dans cet article. Nous ne devons pas gaspiller notre héritage antibiotique. Cet outil nouveau et de valeur doit être employé correctement; il n'autorise pas un relâchement dans nos habitudes de traitement et de prévoyance, mais plutôt le contraire'.

Ceci reste la conclusion aujourd'hui.

\section{Discussion}

\section{MR. AMBROSE KING}

Perhaps I may open this discussion from the Chair, particularly in relation to Dr. Willcox's paper because he appears to have pointed a finger at me. In fact he and I have debated this matter on a number of occasions in a friendly fashion but with considerable disagreement. 
Let me first quote from the abstract of his paper:

The importance of students and physicians being taught regarding the correct use of this valuable method of venereal disease control, at least for those patients who are unable or unlikely to attend again, is stressed.

This is the crux of the matter. Dr. Willcox knows as well as you and I how difficult it is to teach the students and physicians to practise and maintain reasonably good standards in the diagnosis and treatment of venereal diseases. He knows, too, that there are plenty of lazy people in our profession and practising our special subject. In advocating treatment without diagnosis in over-enthusiastic fashion he is doing a very dangerous thing. He will discriminate, but others will not. To some the broad interpretation of the message will be that the tedious routine of investigation can be abandoned in favour of epidemiological treatment and it will be all right because Dr. Willcox says so.

He has taken great pains to establish an analogy with a number of diseases for which prophylaxis is used, but most of this is irrelevant because the diseases in question do not depend on human behaviour and carry none of the psychological problems of guilt, anxiety, or disproportionate fear. He has included two sexually communicable diseases, one of which is trivial and carries no threat to the future health of the patient and family and the other a condition of unknown cause for which we sometimes have to treat contacts because of our ignorance and uncertainty and the possibility of reinfection.

Another major disadvantage of his procedure in cases of syphilis and gonorrhoea is that, once treatment has been given in the absence of a firm diagnosis, the tracing of the patient's other sexual contacts becomes impossible because it cannot be justified unless a diagnosis has been made.

It has seemed to me that, wherever epidemiological treatment is advocated and practised, the venereal diseases seem to flourish with exceptional vigour. The effectiveness of this measure in combating them is very open to question.

Let me once again express my belief that the widespread use of this procedure is unscientific and fundamentally unsound. It is potentially dangerous to patients and their families. However careful and discriminating Dr. Willcox's own use of the method may be, his overenthusiastic advocacy is unwise and likely to give a totally false impression.

Most of us have probably been forced into the position of giving this type of treatment in a very occasional case in exceptional circumstances. Its use is a matter of judgement and it is undertaken unwillingly. The method should never be recommended to the inexperienced and inexpert.

\section{DR. H. BIJKERK}

I endorse the policy of epidemiological treatment advocated by Dr. Willcox. Mr. King fears that the general acceptance of epidemiological treatment would lead to a serious reduction in contact-tracing activity. Epidemiological treatment, however, still requires very active contact tracing in order to find all the possible infected contacts of an established case of infectious early syphilis or gonorrhoea. The doctor should, therefore, be repeatedly reminded of his responsibility both in carrying out contact tracing and in requesting the help of the venereal diseases services in doing so.

\section{DR. C. S. NICOL}

Patients who are given epidemiological treatment are not included in the quarterly and annual returns to the Department of Health. The widespread use of epidemiological treatment without diagnosis leads to a serious degree of under-reporting of the common sexually transmitted diseases.

\section{DR. R. D. CATTERALL}

Is there any evidence that epidemiological treatment really works and results in control of sexually transmitted diseases? Experience in the United States suggests that it does not work. The U.S. Public Health Service stated a few years ago that they would eradicate syphilis in America, but the incidence of syphilis is rising rapidly in that country despite the widespread and almost universal use of epidemiological treatment. This method has led to a serious deterioration in the standards of clinical practice. The members of the World Health Organisation Travelling Seminar who recently visited the United States were struck by the low standards prevailing in most clinics in the U.S.A. Several doctors told members of the seminar that there was no point in examining patients if they were to be given epidemiological treatment anyway.

The biological implications of epidemiological treatment are quite unknown. Doctors using this technique do not know what they are doing to their patients. There is no way of measuring the effects of treatment and the whole procedure is most unscientific. It is interesting that surgeons have recently abandoned the use of prophylactic antibiotics because of the dangers of changes in the bacterial flora of the patient. If this method of treatment is widely employed it will encourage the emergence of resistant strains of organisms. No disease has been completely eradicated by treatment alone and the examples of myxomatosis in rabbits and malaria in the mosquito show how readily organisms adapt to agents intended to destroy them.

There is frequently a conflict between the duties of the physician to his patient and the demands of the public health authorities. In many instances it is the physician's duty to protect his patients from the over-zealous application of the public health rules by those primarily interested in statistics and organizational problems. To the physician the individual remains the most important unit and his responsibilities to his individual patients have absolute priority. In many instances epidemiological treatment is not in the best interests of the individual patient.

\section{DR. J. L. FLUKER}

I cannot accept that in advanced countries epidemiological treatment is anything but undesirable. Treatment before diagnosis is contraindicated as a general medical 
principle. If we infringe this, how can we educate our already ignorant and often prejudiced colleagues as well as the medical students whom we may have to teach, that the indiscriminate administration of antibiotics to all and sundry is not the chief feature of venereology? Nor is there any real evidence that in advanced countries such methods would have any effect in controlling the number of cases. For example, despite an overwhelming increase in the total number of new cases in many clinics in the United Kingdom, the incidence of early syphilis remains at a very low level despite the complete absence of epidemiological treatment. Certainly this is true in my own department, where such treatment of syphilis would not be allowed.

So far as gonorrhoea is concerned, I have twice been involved in divorce cases in which a married woman had been treated epidemiologically elsewhere, thus destroying valuable medico-legal evidence and prejudicing her chances of obtaining a divorce. On the other hand, in suspected cases of gonorrhoea, medical reasons such as early salpingitis might well justify immediate treatment after a single set of negative smears. Similarly, a young woman of low intelligence and devoid of social conscience or a habitual prostitute given to rapid disappearances from the scene-and in these cases the advice of the welfare officer may be invaluable-ought on occasion to be given treatment if re-attendance is thought to be unlikely. But this immediate treatment before diagnosis must be kept to a minimum and must depend upon the judgement of the physician treating the case. Indeed, knowing when to apply such epidemiological treatment in selected cases is part of the art of medicine, which requires both intuition and experience.

\section{DR. A. S. WIGFIELD}

For 20 years I have undertaken the epidemiological treatment of innocent wives known to be at risk from husbands whose gonorrhoea was admittedly acquired outside the marriage and prior to the last marital intercourse. Such patients are not told the real nature of the situation, although the diagnosis may be revealed in answer to direct questioning. I have had no legal, medical, or social repercussions.

I found that my predecessor in Newcastle upon Tyne had extended this epidemiological practice to fiancées, unmarried expectant mothers, and known prostitutes. The latter, anxious for their reputations, come for routine check-ups when they suspect they are infected. It is the experience in Newcastle that these women, on learning that their smears are negative, do not readily return to the clinic. They often give false addresses and are already lost to the clinic when the culture results come back positive 2 days later. It is then that one regrets not having indulged in epidemiological treatment. The net is more widely cast today to include regular girl friends similarly at risk from known male cases. These patients usually know what the investigation is all about, and they are not treated surreptitiously but are invited to take treatment as a wise precaution, which they invariably do.
I admit the danger of confusing the epidemiological treatment of the known contacts of proven cases with the haphazard prophylactic treatment which doctors outside the specialty of venereology may offer their patients either before they go for a night out or after possible risk. This 'prophylaxis' which was practised in the American armed forces has had undesirable consequences when one considers the resistance of the gonococcus to penicillin which developed in Philippino prostitutes.

In short, epidemiological treatment is all right 'for us' but not 'for them'.

\section{DR. R. R. WILLCOX}

I expected that the Chairman would not remain impartial on this occasion and indeed most of us would have been disappointed had he done so. I have, however, never advocated indiscriminate epidemiological or prophylactic treatment and it is unfair to suggest that I have done so, over-enthusiastically or otherwise. As for the objection that doctors cannot be taught discrimination, they are surely able to master far more difficult procedures than that under consideration.

An association between the use of epidemiological treatment and high rates of venereal disease may exist, but not in the manner suggested. Rather, in many areas, it is the high prevalence of disease, associated perhaps with insufficient facilities, mobile populations, or other local factors, which has dictated its use. In the U.S.A., in my opinion, it is not epidemiological treatment but rather the high proportion of cases treated by private practitioners and their failure to report their cases which have led to the recent increase in syphilis. How much worse might the situation have been without it ?

Like Dr. Wigfield, I have experienced no legal or other repercussions from giving such treatment. Indeed, as divorce has become easier, venereal disease has been used less and less as a reason. In any case, in respect of gonorrhoea, it is usually impossible to state which partner has the disease first. I have not been required to go to court in respect of a venereal disease matter for over 20 years and there does not seem sufficient grounds for such a rarity to limit the use of epidemiological treatment, especially as it does not need to be offered immediately in marital cases in which medico-legal factors are likely to arise.

It is particularly difficult to understand the inconsistency of those who approve its use in non-behavioural disorders, for a trivial sexually-transmitted disease like trichomoniasis, and for non-gonococcal urethritis-a condition shrouded by ignorance and obscurity-and yet disapprove of it for the more serious venereal diseases where it can be shown to do the most good in terms of prevention, and particularly when behavioural patterns of promiscuity and default of patients provide compelling reasons. Surgeons may have discarded the use of prophylactic antibiotics for bowel surgery, but this is not true for the surgical indications listed in my paper, namely cardiac surgery and mid-thigh amputation. 
I believe that epidemiological treatment, properly applied, is in the best interests of the patient. I have seldom known a patient refuse it and many have requested it spontaneously. Anxiety is more often bred by not giving it. Indeed prophylactic treatment is also sometimes in the best interests of the patient and his advisers. I recently had referred to me a high-born foreign visitor who had exposed himself with a girl from a night club and who desired prophylactic treatment. Influenced, perhaps, by Mr. King, I did not agree to give it and the patient developed gonorrhoea! My advice was not considered good by the patient, by his general practitioner, or in retrospect by myself!
As regards the reporting of cases, the clinics of England and Wales now have perhaps the most comprehensive quarterly returns of any country. If anxiety exists as to the lack of data it will be a simple matter to include the numbers of test-negative contacts of patients with gonorrhoea who are given epidemiological treatment.

In conclusion, I have observed that none of the speakers never use epidemiological treatment and the extent varies from the considerable to the minimum. I heartily endorse Dr. Fluker's statement that knowing when to apply it in selected cases is part of the art of medicine, and I note that some are more artful than others. 